\title{
Evaluation of antibacterial activity of silver nanoparticles synthesized by a novel strain of marine Pseudomonas sp.
}

Roshmi Thomas ${ }^{1}$,Aswathy Viswan ${ }^{1}$, Jyothis Mathew ${ }^{1}$ and Radhakrishnan $\mathrm{EK}^{1 *}$

${ }^{1}$ School of Biosciences, Mahatma Gandhi University, PD Hills (PO), Kottayam, Kerala, 686560, India

*Corresponding author: radhakrishnanek@mgu.ac.in

Tel/fax.: +91-9847901149

\begin{abstract}
Use of silver nanoparticles to manage pathogenic microorganisms is a modern trend in nanomedicine. Thus our study focused on utilizing the nanoparticle synthesizing properties of marine bacteria. Molecular identification of the selected bacterial strain was done by 16 SrDNA sequencing based method, which showed it as a novel Pseudomonas strain. The biosynthesis of silver nanoparticles was obtained by treating the bacteria with 1 $\mathrm{mM} \mathrm{AgNO}_{3}$ and the isolate was found to have the ability to form silver nanoparticles intracellularly within 24 hours at room temperature. The silver nanoparticles synthesized by the novel isolate were characterized by UV-Vis spectroscopy and scanning electron microscope. The UV-Vis absorption analysis showed a peak at $430 \mathrm{~nm}$ corresponding to the surface plasmon resonance of silver nanoparticles. Also these silver nanoparticles were evaluated for their antibacterial efficacy against Salmonella typhi, Vibrio cholerae, Bacillus subtilis and Staphylococcus aureus.
\end{abstract}

Keywords: silver nanoparticles, marine Pseudomonas sp., intracellular, antibacterial activity, purification.

Citation: R. Thomas et al. Evaluation of antibacterial activity of silver nanoparticles synthesized by a novel strain of marine Pseudomonas $s p$. Nano Biomed. Eng. 2012, 4(3), 139-143. DOI: 10.5101/nbe.v4i3.p139-143.

\section{Introduction}

Nanotechnology deals with the materials which exhibit remarkable physical, chemical and biological properties because of their nanoscaled size. Biological nanoparticle synthesis mainly include use of various microbes like bacteria, actinomycetes, yeast and fungi for the reaction [1-4]. The physical properties of nanoparticles are determined by their size and shape and these factors could be better controlled in biological method of synthesis [57]. Since this synthesis processes takes place at ambient temperature and pressure, it is much economical also [810]. In addition to this, the ease of culturing, handling and genetic manipulation makes bacteria as a promising group of microorganism for nanoparticle synthesis [11].

Nanotechnology finds its application in various areas of medicine ranging from diagnosis, therapeutic drug delivery to treatment of many diseases. Silver nanoparticles (AgNPs) are one of the promising products in the field of nanotechnology because of its application as antimicrobials, therapeutics, biomolecular detection and catalysis $[12,13]$. The small size and large surface area of AgNPs is important in its antimicrobial activity [14-17].
Silver nanoparticles can have strong antibacterial activity towards both gram positive and gram negative bacteria $[18,19]$. Several studies propose that the antimicrobial activity of AgNPs as due to the slow release of silver ions which react with thiol groups of proteins or interfere with DNA replication [20,21]. Also silver nanoparticles may get attached to the cell membrane surface which inturn can damage or disturb the functions of the cell leading to bacterial death [22-24]. This makes studies on synthesis of AgNPs much important.

The physical and chemical properties of nanoparticles generated through various biological methods makes them to have diverse functions and applications. Thus, studies on these properties from bacteria of diverse origin are much attractive. In the current study, a bacterial isolate identified from least explored marine environment was studied for the intracellular synthesis of AgNPs. The isolated organism was identified as a novel strain of Pseudomonas sp. by molecular methods. The biosynthesized AgNPs were characterized by UV-Vis spectroscopy and SEM. Also the microbially generated 
AgNPs were studied for its antibacterial efficacy against clinically important bacterial pathogens such as Salmonella typhi, Vibrio cholerae, Bacillus subtilis and Staphylococcus aureus.

\section{Materials and methods}

\subsection{Isolation of bacteria}

Seawater samples collected from Baypore beach, Kerala, India were serially diluted in sterile $0.8 \% \mathrm{NaCl}$ and were plated onto Sea Water Nutrient agar media (Peptone $5 \mathrm{~g}$, Yeast extract $1.5 \mathrm{~g}$, Beaf extract $1.5 \mathrm{~g}$, Sodium chloride $15 \mathrm{~g}$, Aged sea water $500 \mathrm{~mL}$, Distilled water $500 \mathrm{~mL}$ and Agar $15 \mathrm{~g}$ ) and incubated at room temperature for $48 \mathrm{hrs}$. The colonies obtained were further sub cultured on Sea water nutrient agar. After the incubation period, randomly selected colony BB4 was used for nanoparticle synthesizing studies.

\subsection{Molecular identification}

Molecular identification of the selected strain was conducted by $16 \mathrm{SrDNA}$ sequence based method. For this, total genomic DNA from the isolate was used as template for PCR using 16SrDNA specific primers $27 \mathrm{~F}$ (5'-AgA gTTTgA TCM Tgg CTC-3') and 1525R (5'AAg gAggTg WTC CAR CC-3'). The PCR was carried out in a total volume of $50 \mu \mathrm{L}$ containing $50 \mathrm{ng}$ of genomic DNA, 20 pmoles of each primer, 1.25 units of Taq DNA polymerase, $200 \mu \mathrm{M}$ of each dNTPs and $1 \mathrm{X}$ PCR buffer as components. The PCR was performed for 35 cycles in a Mycycler ${ }^{\mathrm{TM}}$ (Bio-Rad, USA) with the initial denaturation for $3 \mathrm{~min}$ at $94{ }^{\circ} \mathrm{C}$, cyclic denaturation for $30 \mathrm{sec}$ at $94{ }^{\circ} \mathrm{C}$, annealing for $30 \mathrm{sec}$ at $58{ }^{\circ} \mathrm{C}$ and extension for $2 \mathrm{~min}$ at $72{ }^{\circ} \mathrm{C}$ with a final extension of 7 min at $72{ }^{\circ} \mathrm{C}$. After the PCR, the reaction product was analysed by electrophoresis using $1.2 \%$ agarose gel. The product was purified and was subjected to sequencing PCR using the Big Dye Terminator Sequence Reaction Ready Mix (Applied Biosystem). After the reaction, product was purified, precipitated and sequenced in the DNA sequencer ABI 310 Genetic Analyser. The sequence data of $16 \mathrm{SrDNA}$ thus obtained was further aligned using BioEdit programme. This sequence was then used for BLAST analysis. The phylogenetic analysis of the 16SrDNA sequence of the isolate obtained in the study was also conducted using neighbor-joining method in MEGA5 [25].

\subsection{Synthesis of silver nanoparticles}

For nanoparticles synthesis studies, the bacterial isolate was freshly inoculated in to $100 \mathrm{~mL}$ of sea water nutrient broth. This was then incubated in a rotating shaker at room temperature and agitated at $200 \mathrm{rpm}$ for $24 \mathrm{~h}$. After incubation, the biomass and supernatant were separated by centrifugation at $10,000 \mathrm{rpm}$ for $10 \mathrm{~min}$. Both the separated biomass and supernatant were used for the synthesis of silver nanoparticles. One $\mathrm{ml}$ of bacterial supernatant was mixed with $99 \mathrm{~mL}$ of filter sterilized 1 $\mathrm{mM} \mathrm{AgNO}_{3}$ solution for extracellular synthesis. At the 140 same time $2 \mathrm{~g}$ of bacterial wet biomass was resuspended in $100 \mathrm{~mL}$ aqueous solution of $1 \mathrm{mM} \mathrm{AgNO}_{3}$ in a 250 $\mathrm{mL}$ Erlenmeyer flask for intracellular synthesis. All the mixtures were kept on rotating shaker set at $200 \mathrm{rpm}$ for a period of $72 \mathrm{~h}$ at room temperature in light and dark conditions. The biomass and supernatant incubated without silver nitrate and silver nitrate solution alone were also maintained as control. The bioreduction of $\mathrm{Ag}^{+}$ions was monitored by changes in colour. Also the optical characteristics of synthesized silver nanoparticles were measured using UV-visible spectrophotometer. The absorption spectra of the biomass were taken on UVVisible spectrophotometer (Hitachi U5100) at 200-800 $\mathrm{nm}$ range with control as reference.

\subsection{Purification of silver nanoparticles from biomass}

Purification of silver nanoparticles was carried out from intracellular synthesis reactions. For this, the bacterial pellets were collected by centrifugation at $10,000 \mathrm{rpm}$ for $10 \mathrm{~min}$ under sterile conditions. The pellets were washed and resuspended in $50 \mathrm{mM}$ Tris buffer ( $\mathrm{pH} 7)$. Then the cells were disrupted by ultrasonication for 3 times, on/off cycle of $59 \mathrm{~s}$. The cell debris was removed by centrifugation at $15,000 \mathrm{rpm}$ for $15 \mathrm{~min}$. The resulting supernatant was used for further characterization of silver nanoparticles as per previous reports [1].

\subsection{Characterization of silver nanoparticles}

Purified silver nanoparticles produced from biomass were air-dried and analyzed using SEM. SEM analysis of dried samples was performed by mounting nanoparticles on specimen stubs with double adhesive tape and coated with platinum in a sputter coater and examined under JEOL 6390 SEM JSM at $10 \mathrm{KV}$.

\subsection{Determination of antibacterial activity by well diffusion method}

The AgNPs synthesized from the selected isolate was tested for its antibacterial activity against pathogenic bacteria such as Salmonella typhi, Vibrio cholerae, Bacillus subtilis and Staphylococcus aureus by standard well diffusion method in Mullor Hinton Agar (MHA) plates as per previous reports $[18,26]$. Pure cultures of bacterial pathogens were grown in Nutrient broth at 37 ${ }^{\circ} \mathrm{C}$ for 18-24 hours. Wells were made on the MullorHinton agar plates using a gel puncture and the plates were inoculated by swabbing the bacterial pathogens to create a confluent lawn of bacterial growth. Then $40 \mu \mathrm{L}$ of the biosynthesized AgNPs solution was poured on to corresponding well using a micropipette. As control, 40 $\mu \mathrm{L}$ of $1 \mathrm{mM} \mathrm{AgNO}_{3}$ solution was poured on to control well. After incubation at $37{ }^{\circ} \mathrm{C}$ for 24 hours, diameter of zone of inhibition in millimeter around each well was measured.

\section{Results and Discussion}

Molecular identification of the bacterial strain BB4 isolated from Baypore beach was done by $16 \mathrm{SrDNA}$ sequencing based method. The sequence data of the 
strain was subjected to BLAST analysis where it showed $94 \%$ identity to $16 \mathrm{SrDNA}$ sequence of various Pseudomonas sp. mainly Pseudomonas grimontii strain. The 16SrDNA sequence of the isolate was submitted to NCBI under the accession number JX417979. The 16SrDNA sequence of the isolate used in the study was also used for phylogenetic analysis; the result showed distinct clustering of the 16SrDNA sequence of BB4 with the sequence of Pseudomonas grimontii (Data not shown). So the isolate can be considered as a novel strain of Pseudomonas sp. which can be represented as Pseudomonas sp. BB4. The novelty of the isolate and its isolation from from marine source made it an interesting candidate for nanoparticles synthesizing studies.

Both the intracellular and extracellular synthesis reaction of silver nanoparticles by the isolate $\mathrm{BB} 4$ were visually monitored by colour change from pale yellow to brown as per previous reports [27-29]. Such a change in colour from pale yellow to brown was observed only with the biomass of the isolated strain treated with $1 \mathrm{mM}$ $\mathrm{AgNO}_{3}$ within $24 \mathrm{~h}$ of incubation (Fig. 1). This indicated that intracellular components of the strain reduced $\mathrm{Ag}^{+}$ ions to $\mathrm{Ag}^{0}$ and the colour change is due to the excitation of surface plasmon resonance of silver nanoparticles $[26,30]$. Also the bioreduction of $\mathrm{Ag}^{+}$ions was occurred only in the presence of light and there are several reports on the effect of visible light on the biosynthesis of silver nanoparticles [31,32]. The exact role of light in AgNPs biosynthesis is not known, but it may be due to the involvement of carboxylic acid containing peptides [33]. There was no colour change for the supernatant treated with $1 \mathrm{mM} \mathrm{AgNO}_{3}$ solution either in the presence or absence of light. Thus there was no extracellular reduction of $\mathrm{Ag}^{+}$ions for the isolate used in the study. Also experimental controls like biomass and supernatant of the strain incubated without silver nitrate and silver nitrate solution alone showed no colour change. Thus the visual observation of brown colour in sample containing bacterial biomass and $1 \mathrm{mM} \mathrm{AgNO}$ can be due to the intracellular synthesis of silver nanoparticles. This colour

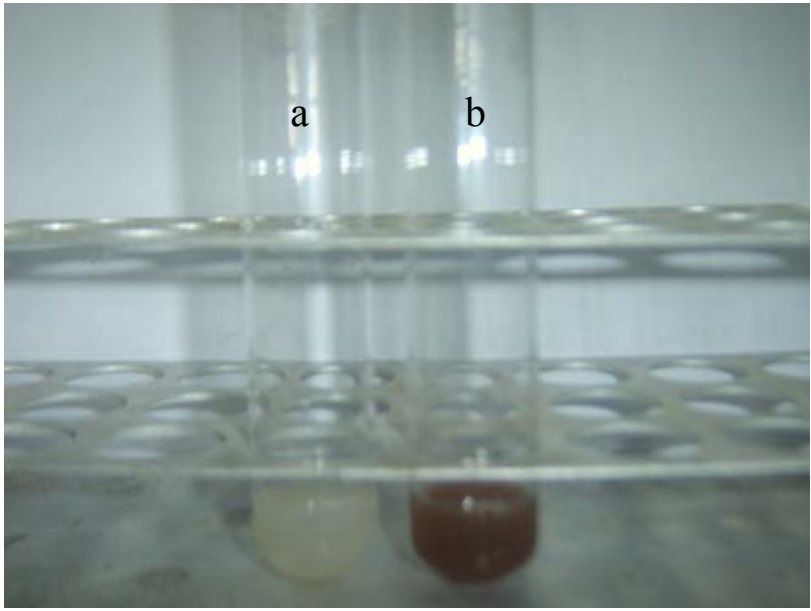

Fig. 1 Visual observation of the biosynthesis of silver nanoparticles by BB4 isolate after $24 \mathrm{~h}$. (a): control with biomass alone (no color change).(b): bacterial biomass with $\mathrm{AgNO}_{3}$ solution (color change from pale yellow to brown). change as an indication of biosynthesis of AgNPs were previously reported for the biomass of $B$. licheniformis and B.cereus $[1,28]$.

The AgNPs synthesized intracellularly by the Pseudomonas sp. BB4 used was first characterized using UVVis spectrophotometer in the range of 200-800 $\mathrm{nm}$ as per previous reports [30]. UV-Visible spectra of silver nanoparticle synthesized by the Pseudomonas sp. BB4 showed a strong absorption band at $430 \mathrm{~nm}$ and these absorption spectra obtained within short interaction time of 24 hours (Fig. 2). This intense absorption peak of silver nanoparticles is due to its surface plasmon excitation which inturn is because of the collective excitation of conduction electron in metal. It was reported that silver nanoparticles synthesized by Bacillus licheniformis showed such a peak assigned to a surface plasmon resonance of silver nanoparticles [28]. The presence of AgNPs was further confirmed by SEM analysis. For that, the samples were subjected to purification process and purified nanoparticles were used for SEM analysis. The SEM micrograph of purified nanoparticles showed the presence of more or less spherical silver nanoparticles with the size ranging between 156 and $265 \mathrm{~nm}$ (Fig. 3).

The antibacterial activity of biosynthesized silver

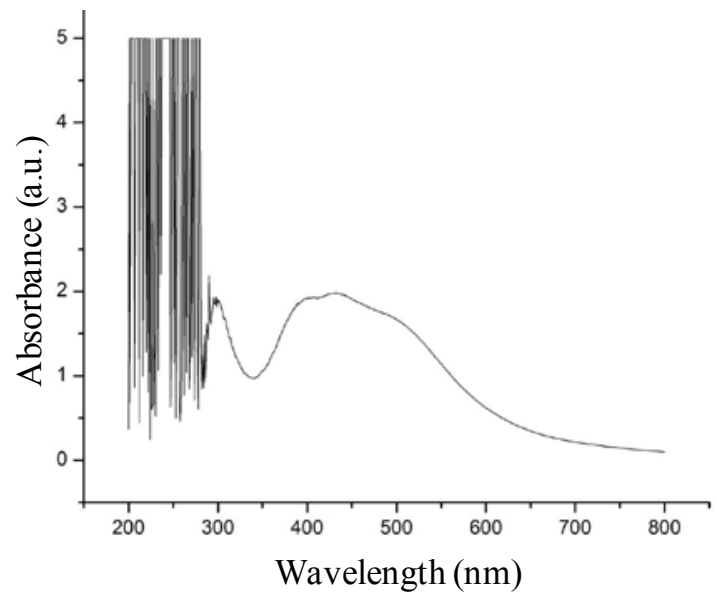

Fig. 2 The UV-Vis absorption spectrum of silver nanoparticles synthesized by biomass of BB4 isolate. The absorption spectrum of silver nanoparticles exhibited a strong broad peak at $430 \mathrm{~nm}$. Observation of such a band is assigned to surface plasmon resonance of the particles.

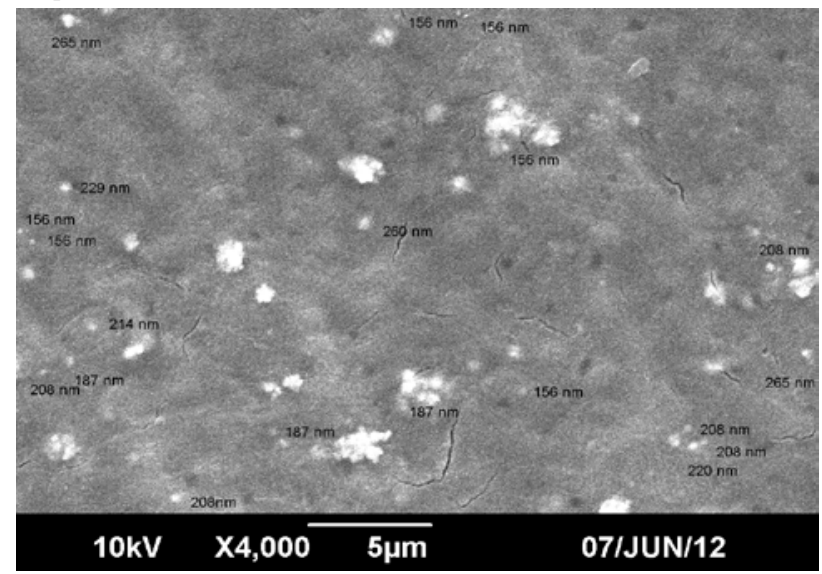

Fig. 3 SEM image of the silver nanoparticles synthesized by BB4 isolate with $1 \mathrm{mM}$ silver nitrate solution 
http://nanobe.org

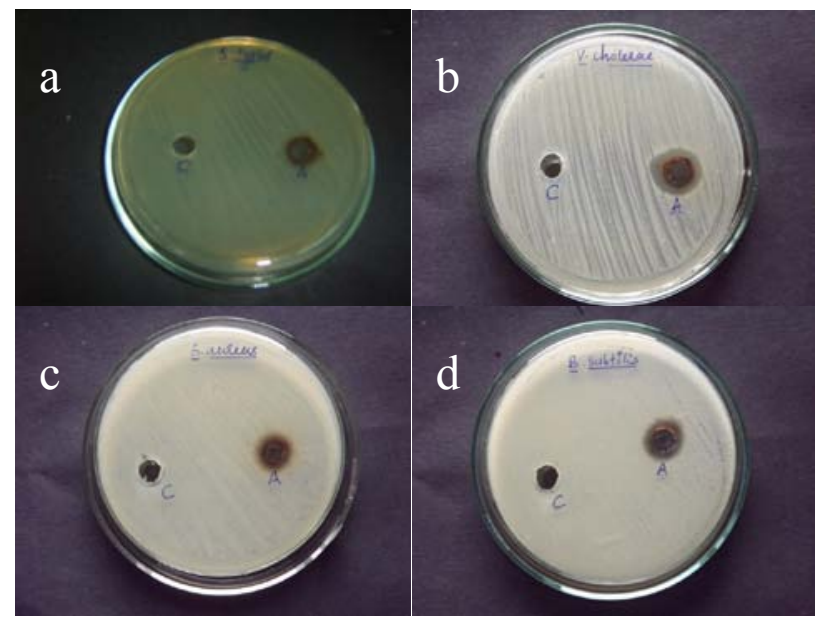

Fig. 4 Antibacterial activity of AgNPs synthesized by BB4 isolate towards (a) Salmonella typhi (b)Vibrio cholerae (c) Staphylococcus aureus (d) Bacillus subtilis. Each plate shows (A) AgNPs synthesized by BB4 isolate (C) $1 \mathrm{mM} \mathrm{AgNO}_{3}$ control.

Table 1. Diameter of zone of inhibition by biosynthesized AgNPs against pathogenic gram positive and gram negative bacteria.

\begin{tabular}{|l|c|}
\hline \multicolumn{1}{|c|}{ Pathogenic bacteria } & $\begin{array}{c}\text { Zone of inhibition } \\
\text { (mm in diameter) }\end{array}$ \\
\hline Salmonella typhi & 14 \\
\hline Vibrio cholerae & 18 \\
\hline Staphylococcus aureus & 15 \\
\hline Bacillus subtilis & 16 \\
\hline
\end{tabular}

nanoparticles was performed against both gram positive (Staphylococcus aureus and Bacillus subtilis) and gram negative (Salmonella typhi and Vibrio cholerae) bacteria by well diffusion method. The AgNPs synthesized from the isolate showed excellent antibacterial activity against all tested bacterial strains at volume of $40 \mu \mathrm{L} /$ well (Fig. 4). After 18 hours of incubation, zone of inhibition of $14 \mathrm{~mm}, 18 \mathrm{~mm}, 15 \mathrm{~mm}$ and $16 \mathrm{~mm}$ were observed for the AgNPs against Salmonella typhi, Vibrio cholerae, Staphylococcus aureus and Bacillus subtilis respectively (Table 1). Previous reports of antibacterial activity of silver nanoparticles against Salmonella typhi [26], Staphylococcus aureus [19] Vibrio cholerae [34] and Bacillus subtilis [18] support this result.

\section{Conclusion}

The current study demonstrates synthesis of silver nanoparticles by a novel strain of Pseudomonas sp. Microorganisms have huge potential for the production of nanoparticles and thus isolation of novel microbes from unexplored sources is a promising step for the identification of microbes with the ability to form nanoparticles. The selected isolate in the study is a potential candidate for the synthesis of silver nanoparticles and the biosynthesized silver nanoparticles has shown excellent antibacterial activity against clinically important pathogens.

\section{Acknowledgements}

The authors gratefully acknowledge School of Chemical Sciences, Mahatma Gandhi University, Kottayam, Kerala, India for the help and support for the SEM analysis of samples and also to DBT-RGYI Programme for the instrumentation facility.

\section{References}

1 Babu G, Gunasekaran P. Production and structural characterization of crystalline silver nanoparticles from Bacillus cereus isolate. Colloids Surf. B. Biointerfaces. 2009; 74:191-195. http://dx.doi.org/10.1016/j.colsurfb.2009.07.016.

2 Sadhasivam S, Shanmugam P, Yun K. Biosynthesis of silver nanoparticles by Streptomyces hygroscopicus and antimicrobial activity against medically important pathogenic microorganisms. Colloids Surf. B. Biointerfaces. 2010; 81:358-362. http://dx.doi.org /10.1016/j.colsurfb.2010.07.036.

3 Mourato A, Gadanho M, Lino AR, Tenreiro R. Biosynthesis of crystalline silver and gold nanoparticles by extremophilic yeasts. Bioinorg. Chem. Appl. 2011; 1-8. http://dx.doi.org/10.1155/2011/546074

4 Kathiresan K, Alikuhni NM, Pathmanabhan S, Nabikhan A, Kandasamy S. Ananlysis of antimicrobial silver nanoparticles synthesized by coastal strains of Escherichia coli and Aspergillus niger. Can.J.Microbiol. 2010; 56:1050-1059. http://dx.doi.org/10.1139/W10-094.

5 Burda C, Chen X, Narayanan R, El-Sayed MA. Chemistry and properties of nanocrystals of different shapes. Chem. Rev. 2005; 105:1025-1102. http://dx.doi.org/10.1021/cr030063a.

6 Vaidyanathan R, Gopalram S, Kalishwaralal K, Deepak V, Pandian SRK, Gurunathan S. Enhanced silver nanoparticle synthesis by optimization of nitrate reductase activity. Colloids Surf. B. Biointerfaces. 2010; 75:335-341. http://dx.doi.org/10.1016 /j.colsurfb.2009.09.006

7 Sintubin L, De Windt W, Dick J, Mast J, van der Ha D, Verstraete W, Boon N. Lactic acid bacteria as reducing and capping agent for the fast and efficient production of silver nanoparticles. Appl. Microbiol. Biotechnol. 2009; 84: 741-749. http: //dx.doi.org/10.1007/s00253-009-2032-6.

8 Mukherjee P, Roy M, Mandal B, Dey G, Mukherjee P, Ghatak J. Green synthesis of highly stabilized nanocrystalline silver particles by a non-pathogenic and agriculturally important fungus T. asperellum. Nanotechnology. 2008; 19:75103. http:// dx.doi.org/10.1088/0957-4484/19/7/075103.

9 Banu A, Rathod V, Ranganath E. Silver nanoparticle production by Rhizopus stolonifer and its antibacterial activity against extended spectrum $\beta$-lactamase producing (ESBL) strains of Enterobacteriaceae.Mater. Res. Bull. 2011; 46:1417-1423. http://dx.doi.org 10.1016/j.materresbull.2011.05.008.

10 Gade AK, Bonde P, Ingle AP, Marcato PD, Duran N, Rai MK. Exploitation of Aspergillus niger for synthesis of silver nanoparticles.J Biobased Mater. Bioenergy.2008; 3:123-129.

11 Klaus T, Joerger R, Olsson E, Granqvist CG. Silver-based crystalline nanoparticles, microbially fabricated. Proc. Natl. Acad. Sci. USA . 1999; 96:13611-13614. http://dx.doi.org/10.1073/pnas.96.24.13611.

12 Rai M, Yadav A, Gade A. Silver nanoparticles as a new generation of antimicrobials. Biotech. Adv. 2009; 27:76-83. http://dx.doi.org /10.1016/j.biotechadv.2008.09.002.

13 Mann S. Ozin GA. Synthesis of inorganic materials with complex form. J. Nat. 1996; 382:313-318. http://dx.doi.org/10.1038/382313a0

14 Guzmán MG, Dille J, Godet S. Synthesis of silver nanoparticles by chemical reduction method and their antibacterial activity. Int. J. Chem. and Bio Eng. 2009; 2:104-111.

15 Eychmüller A, Rogach AL. Chemistry and photophysics of thiolstabilized II-VI semiconductor nanocrystals. Pure Appl. Chem. 2000; 72:179-188. http://dx.doi.org/10.1351/pac200072010179.

16 Trindade T, O'Brien P, Pickett NL. Nanocrystalline semiconductors: Synthesis, properties, and perspectives. Chem. Mater. 2001; 13:3843-3858. http://dx.doi.org/10.1021/cm000843p.

17 Arunachalam R, Dhanasingh S, Kalimuthu B, Uthirappan M, Rose C, Mandal AB. Phytosynthesis of silver nanoparticles using Coccinia grandis leaf extract and its application in the photocatalytic degradation. Colloids Surf. B. Biointerfaces. 2012; 94:226-230. http://dx.doi. 
org/10.1016/j.colsurfb.2012.01.040.

18 Sadhasivam S, Shanmugam P, Yun K. Biosynthesis of silver nanoparticles by Streptomyces hygroscopicus and antimicrobial activity against medically important pathogenic microorganisms. Colloids Surf. B. Biointerfaces. 2010; 81:358-362. http://dx.doi.org/10.1016/ j.colsurfb.2010.07.036.

19 Nanda A, Saravanan M. Biosynthesis of silver nanoparticles from Staphylococcus aureus and its antimicrobial activity against MRSA and MRSE. Nanomeicine. 2009; 5:452-456. http://dx. doi.org/10.1016/j.nano.2009.01.012.

20 Liau SY, Read DC, Pugh WJ, Furr JR, Russel AD. Interaction of silver nitrate with readily identifiable groups:relationship to the antibacterial action of silver ions. Lett. Appl.Microbiol. 1999; 25: 279-283. http://dx.doi.org/10.1046/j.1472-765X.1997.00219.x.

21 Feng QL, Wu J, Chen GQ, Cui FZ, Kim TN, Kim JO. A mechanistic study of the antibacterial effect of silver ions on Escherichia coli and Staphylococcus aureus. J Biomed. Mater. Res. 2000; 52:662-668. http://dx.doi.org/10.1002/1097-4636(20001215)52:4<662::AIDJBM10>3.0.CO;2-3.

22 Kim JS, Kuk E, Yu KN, Kim J, Park SJ, Lee HJ, Kim SH, Park YK, Park YH, Hwang C, Kim Y, Lee Y, Jeong DH, Cho M. Antimicrobial effects of silver nanoparticles. Nanomed. Nanotechnol. Biol. Med. 2007; 3:95-101. http://dx.doi.org/10.1016/j.nano.2006.12.001.

23 Kumar SA, Abyaneh MK, Gosavi SW, Kulkarni SK, Pasricha R, Ahmad A, Khan MI. Nitrate reductase-mediated synthesis of silver nanoparticles from AgNO3. Biotechnol. Lett. 2007; 29:439-445. http://dx.doi.org/10.1007/s10529-006-9256-7.

24 Melaiye A,Young WJ. Silver and its application as antimicrobial agent. Expert. Opin. Ther. Pat. 2005; 15:125-130. http://dx.doi.org/ 10.1517/13543776.15.2.125.

25 Tamura K, Peterson D, Peterson N, Stecher G, Nei M, Kumar S. MEGA5: Molecular evolutionary genetics analysis using maximum likelihood, evolutionary distance, and maximum parsimony method. Biol.and evol. 2011; 28:2731-2739.

26 Saravanan M, Venu AK, Barik SK. Rapid biosynthesis of silver nanoparticles from Bacillus megaterium (Ncim 2326) and their antibacterial activity on multi drug resistant clinical pathogens. Colloids Surf. B. Biointerfaces. 2011; 88:325-331. http:// dx.doi.org/10.1016/j.colsurfb.2011.07.009. http://nanobe.org

27 Kannan N, Mukunthan KS, Balaji S. A comparative study of morphology, reactivity and stability of synthesized silver nanoparticles using Bacillus subtilis and Catharanthus roseus (L.) G.Don. Colloids Surf. B. Biointerfaces. 2011; 86:378-383. http:// dx.doi.org/10.1016/j.colsurfb.2011.04.024.

28 Kalimuthu K, Babu RS, Venkataraman D, Bilal M, Gurunathan S. Biosynthesis of silver nanocrystals by Bacillus licheniformis. Colloids Surf. B. Biointerfaces. 2008; 65:150-153. http://dx.doi.org /10.1016/j.colsurfb.2008.02.018.

29 Saifuddin N,Wong CW, NurYasumira AA. Rapid biosynthesis of silver nanoparticles using culture supernatant of bacteria with microwave irradiation. $J$ Chem. 2009; 6:61-70.

30 Ahmad A, Mukherjee P, Senapati S, Mandal D, Khan MI, Kumar R. Extracellular biosynthesis of silver nanoparticles using the fungus Fusarium oxysporum. Colloids Surf. B. Biointerfaces. 2003; 28:313-318. http://dx.doi.org/10.1016/S0927-7765(02)00174-1.

31 Wei H, Chen C, Han B, Wang E. Enzyme colorimetric assay using unmodified silver nanoparticles. Anal. Chem. 2008; 80:7051-7055. http://dx.doi.org/10.1021/ac801144t.

32 Mokhtari N, Daneshpajouh S, Seyedbagheri S, Atashdehghan R, Abdi K Sarkar S, Minaian S, Shaverdi HR, Shaverdi AR. Biological synthesis of very small silver nanoparticles by culture supernatant of klebsiella pneumonia:The effects of visible light irradiation and the liquid mixing process. Mater. Res. Bull. 2009; 44:1415-1421. http:// dx.doi.org/10.1016/j.materresbull.2008.11.021.

33 Nam KT, Lee YJ, Krauland EM, Kottmann ST, Belcher AM. Peptide mediated reduction of silver ions on engineered biological scaffolds. ACS Nano.2008; 2:1480-1486. http://dx.doi.org/10.1021/nn800018n

34 Renugadevi K, Venus Aswini R. Microwave irradiation assisted synthesis of silver nanoparticle using Azadirachta indica leaf extract as a reducing agent and in vitro evaluation of its antibacterial and anticancer activity. Int.J. Nanomat.2012; 2:5-10.

Copyright:(c) 2012 R. Thomas et al. This is an open-access article distributed under the terms of the Creative Commons Attribution License, which permits unrestricted use, distribution, and reproduction in any medium, provided the original author and source are credited. 